\title{
A Content Analysis of Multicultural Children’s Books in the Republic of Korea and America*
}

\author{
Patrick McIver \\ Daegu Catholic University, Gyeongsan-si Hayang-ro, Republic of Korea
}

\begin{abstract}
Picture books are a staple in the kindergarten classroom for teaching content, social expectations, and the joy of reading. The purpose of this study is to explore the representation and depiction of multicultural families in children's picture books within kindergarten classroom libraries. Children's pictures books are a microcosm of today's society. They convey cultural messages and values about society, and help children learn about their heritage and the heritage of others. Children's literature is increasingly more reflective of diverse cultures. Children need to see themselves reflected in literature in order to see the lives of others, and in order to see themselves as able to transverse between groups and worlds. America (U.S.) has been and will always be a diverse nation. Likewise, the Republic of Korea (ROK) is quickly becoming a multicultural society as well, and the influx of multicultural families is growing exponentially. Books depicting this growing diversity can dispose of stereotypes that children may have about races other than their own. Children’s literature is still not authentically portraying a multiethnic Korea. The results of this study show that children who interact with current picture books predominantly see Korean faces. Finding books depicting non-Korean characters, particularly books depicting culturally specific elements, is rare, although there are books depicting culturally neutral and generic characters However, although our classrooms are culturally and ethnically diverse, the books predominantly found in classrooms portray only one race. What does that tell our students? Seeing diverse populations in children’s literature needs to become the norm, not the exception.
\end{abstract}

Keywords: content analysis, multicultural, children's picture books

\section{Introduction}

Children's pictures books are a microcosm of today's society. They convey cultural messages and values about society, and help children learn about their heritage and the heritage of others. The books that children read at home and in the classroom can influence self-awareness (Chaudhri \& Teale, 2013) and can help children develop a positive self-identity (Hall, 2008; Levein, 2007). Picture books are educational tools, and most children come into contact with them. Consequently, their content matters (Koss, 2015).

Multicultural literature encourages children to identify not only with their own culture but also with the

\footnotetext{
* Acknowledgements: This work was supported by a research grant from Daegu Catholic University 2017.

Received: Oct 4, 2017

Accepted: Oct 18, 2017

Patrick McIver, Ph.D., Assistant Professor, Department of English Education, Daegu Catholic University.
} 
cultures of others, thus promoting discussions of diversity (Colby \& Lyon, 2004). Children need to see themselves reflected in literature in order to see the lives of others, and in order to see themselves as able to transverse between groups and worlds.

Children's books are powerful learning tools that help young children understand discrimination (Taylor, 2003). The images that we share with children affect their conceptualization of self and belonging. According to Willett "When children cannot identify with a book or see their lives celebrated through stories, it may have a negative impact on their self-image. The message they get is that their lives and their stories are not important" (Willett, 1995, p. 176). Seeing oneself is critical, but not seeing oneself is even more critical, because children in such a situation may feel marginalized. In addition to being mirrors and windows, books are also maps (Myers, 2014). As children seek their place in the world, they search for where to go and ways to get there. Literature can provide avenues of possibility.

America (U.S.) has been and will always be a diverse nation. Likewise, the Republic of Korea (ROK) is quickly becoming a multicultural society as well, and the influx of multicultural families is growing exponentially. In 2015, the number of multicultural individuals reached over 1.7 million people (Koss, 2015). Books depicting this growing diversity can dispose of stereotypes that children may have about races other than their own. This study will explore how multiculturalism and diversity are characterized, not only in the context of a book, but also in the roles of its narrator and its discourse.

\section{Theoretical Framework}

\section{Impact of Children's Picture Books}

Children's picture books act as a mirror, reflecting and validating students' gendered and cultural identities (Cox \& Galda, 1990). Children’s picture books are an excellent way to introduce children to the variety of ways that people live throughout the world, thus introducing them to the concept of culture (Kuperus, 1992). For children from diverse backgrounds, these stories are windows into a new realm of experiences (Cox \& Galda, 1990). Multicultural literature depicts all types of cultures, which include a variety of races, genders, religions, languages, socioeconomic classes, and ethnicities, and which provide the opportunity to open a child's mind to lifestyles different from his or her own (Katz, 2003). Teaching culture involves providing accurate depictions of the lives of different groups of people (Kuperus, 1992). As children begin this journey of self-awareness, understanding differences between ethnic groups is an important part of social development (Katz, 2003). Picture books that depict a variety of ethnic, racial, and cultural groups within American society allow young children opportunities to develop their understanding of others, while affirming children of diverse backgrounds (Mendoza \& Reese, 2001).

Children's picture books that feature characters from diverse cultures help children become accustomed to the idea that there are many languages, points of view, and ways of living (Freeney \& Moravcik, 2005). Picture books that focus on children from around the world help children to recognize that others not so different from themselves (Freeney \& Moravcik, 2005). Picture books can help children to develop the capacity for empathy through identifying the feelings of others (Taylor, 1976; Lamme \& McKinley, 1992). Children may realize that they sometimes feel the same way as the characters in the picture books (Taylor, 1976; Lamme \& McKinley, 1992). 
The characters and plots of children's books are communicated in ways with which children can identify (Freeney \& Moravcik, 2005). A well-written children's book has well-developed characters who change as a result of life events, and a well-structured plot with enough engaging conflict and suspense to hold a child's interest (Freeney \& Moravcik, 2005). These books can have a positive impact on children's attitudes when they portray people with respect for humanity, and when characters explain why children may feel and act as they do (James, Kormanski \& Kormanski, 1999). Literature that does this reflects children's backgrounds and experiences, and also portrays different races, cultures, abilities, lifestyles, and economic backgrounds (James, Kormanski \& Kormanski, 1999). Picture books can also help children to understand their own experiences, validate their own cultures, provide information about other cultures, encourage empathy, and inspire imagination (Temple et al., 2010). Boutte (2002) asserts that "the power of literature to affect the lives of young children is awesome and far-reaching” (p. 147).

\section{Children's Literature and Social Development}

Picture books articulate culture and sociality for young children. Children's literature can be used to explore and develop appreciation for their own culture and for different cultures (Rasinski \& Padak, 1990; Mann-Boykin, 2016). Norton (1990) observed that, in addition to providing enjoyment, multicultural literature benefits children from an ethnic minority group by allowing them to identify with and feel proud of their heritage, thus boosting their self-esteem and recognition of commonalities such as needs, emotions, dreams, and fears that are shared by all ethnic groups (Mann-Boykin, 2016).

Stories have various interpretations due to differences in cultural backgrounds (Cai, 2002; Langer, 1995; Rosenblatt, 1938). A child's ethnic background and culture play a major role in his or her understanding and the effect of learning (Cai, 2002; Langer, 1995; Rosenblatt, 1938). McGlenn (2001) argued that young children in particular see themselves as the "center of the world" and "want to see themselves and their everyday lives in the stories they read" (p. 50).

Children as young as nine months' notice race (Xiao et al., 2017). Multicultural literature engages the reader regarding people from diverse cultural, linguistic, and religious groups (Canales, Lucido \& Salas, 2002). Young children need to be able to make connections between children picture book and their everyday lives. Picture book stories can provide children with a sense of affirmation about themselves and their culture, and this ability to relate to characters and situations in books can be a major factor in book selection (Colby \& Lyon, 2004). Young children of various ethnic groups need to read about characters who reflect their everyday lives (Colby \& Lyon, 2004).

\section{Multicultural Literature}

Literature performs has two main functions: to entertain and to instruct (Mann-Boykin, 2016). Educators and parents are particularly concerned with the function of instruction, and put a premium on the moral values of children's literature, because it transmits images, ideas, beliefs, attitudes, and values that will be consciously or unconsciously absorbed by impressionable young readers (Cai, 2002).

Multicultural picture books can be used as a tool to engage children and to offer a view of diversity in a story filled with characters from other ethnic groups (Canales, Lucido \& Salas, 2002). For a multicultural picture book to do a culture justice, the characters should be authentic rather than stereotyped (Canales, Lucido \& Salas, 2002). 
The characters must reflect the distinct cultural experiences and views of the specific group that is being portrayed (Diamond \& Moore, 1995).

The images that children enjoy and understand from picture books have a powerful impact on their sense of self and their view of others. In particular, multicultural literature offers minority children the opportunity to see themselves in the materials they read (Freeney \& Moravcik, 2005). Books also act as windows, giving children an opportunity to look outside of themselves to see another person's perspective or another group's worldview (Freeney \& Moravcik, 2005). By engaging young children in reading and voicing their thoughts about the story within the book, children develop familiarity with, understanding of, and respect for a range of human characteristics, including differences in race and culture. When children do not have the direct experiences of a group, they are particularly vulnerable to stereotyping and bias in society and in books (Freeney \& Moravcik, 2005). When children experience books that show unfamiliar people dealing with issues or emotions with which they can identify, they are able to relate to the characters and to begin to gain a sense of common humanity (Freeney \& Moravcik, 2005).

Awareness of ethnicity develops as young children observe attributes such as skin color, hair texture, and facial features (Mann-Boykin, 2016). Fifteen-month old children are aware of racial differences, and are beginning to respond to attributes of difference (Burns \& Summerville, 2014). They may begin by expressing distrust or fear of people who are different than themselves. Child development research demonstrates that by the age of ten, children's attitudes toward race are formed and have become very resistant to change (Burns \& Sommerville, 2016).

Children's picture books that feature characters from diverse cultures can help children become accustomed to the idea that there are many languages, points of view, and ways of living (Freeney \& Moravcik, 2005). Picture books that focus on human beings from around the world help children to recognize that all people need nurturing, food, clothing and shelter; that all people tell stories, dance, and sing; and that all people make things that are useful and beautiful and do so in different and interesting ways (Freeney \& Moravcik, 2005). Picture books can help children to develop the capacity for empathy through identifying with the feelings of others (Taylor, 1976; Lamme \& McKinley, 1992). This may lead children to realize that they sometimes feel the same way as the characters in the picture books feel (Taylor, 1976; Lamme \& McKinley, 1992).

According to Freeney \& Moravcik (2005), preschool- and kindergarten-aged children start to recognize which feelings are appropriate in different situations, and to recognize that both they and others have feelings. Young children slowly grow to understand that the views and feelings of others might be different from their own, and that two people might react differently to the same situation (Freeney \& Moravcik, 2005). Later on in the child's life, he or she learns that two different emotions can be felt at the same time and about the same situation (Freeney \& Moravcik, 2005).

Walking in someone else's shoes can help a child to develop a greater capacity to empathize with others (Lamme \& McKinley, 1992). Through picture books, children may become aware of problems in society, and that not all children's lives are as secure as theirs may be. Hearing stories about these experiences helps children to become more sensitive to problems in society and in the lives of others (Lamme \& McKinley, 1992).

Lamme \& McKinley suggest that children’s picture books guide young children to cope with everyday life problems and extraordinary crises. Issues in children's lives raise strong and often troubling and confusing 
feelings. Picture books can help children learn that they are not the only ones who have ever experienced an event or feeling, and can model ways to think about and act on a problem. This understanding can extend to the problems of others when a child identifies with the development of values such as cooperation, generosity, kindness, compassion, and interdependence, and children's books can provide models of positive ways to relate to others and to solve problems (Taylor, 1976; Berg-Cross \& Berg-Cross, 1978; Black, Seeman \& Trobaugh, 1999).

Children's picture books that young children enjoy deal with the interests and issues in their lives. The characters and plots are communicated in ways with which the children can identify (Freeney \& Moravcik, 2005). A well-written children's book has well-developed characters who change as a result of life events, and a well-structured plot with enough engaging conflict and suspense to hold the child's interest (Freeney \& Moravcik, 2005). Picture books that have a positive impact on children's attitudes portray people with respect for their humanity and explain why children feel and act as they do (James, Kormanski \& Kormanski, 1999). Literature that does this reflects children's backgrounds and experiences, and also portrays different races, cultures, abilities, lifestyles, and economic backgrounds (James, Kormanski \& Kormanski, 1999).

\section{Purpose of the Study}

Picture books are a staple in the kindergarten classroom for teaching content, social expectations, and the joy of reading. The purpose of this study is to explore the representation and depiction of multicultural families in children’s picture books within kindergarten classroom libraries. Multicultural literature can be used as a tool to engage children and to offer a view of diversity in picture books that are filled with characters from other ethnic groups (Canales, Lucido \& Salas, 2002). In particular, multicultural literature offers children the opportunity to see themselves and others in the materials that they read (Freeney \& Moravcik, 2005). Classroom books that challenge historically limiting gender roles and cultural norms counteract stereotypes, and can have a positive effect on the cognitive, social, and gender development of young students (Hamilton, Anderson, Broaddus \& Young, 2006). Children's literature is increasingly more reflective of diverse cultures and gender roles. But how are these diverse books incorporated in classroom libraries?

\section{Methodology}

The study began with a review of 4 kindergartens (2 Korean and 2 American, all located in the ROK), and a total of 20 classrooms were reviewed. Specific criteria for inclusion in the study were established, and the guidelines were strictly enforced to ensure compatibility between the subject matter between the two countries. The study was deliberate, carefully choosing how the study might best serve practitioners. In doing so, the study focused on multicultural children from two distinct countries. Once the criteria were established, a search of classroom libraries on-line, local bookstores, and public libraries was completed. In U.S. classrooms and online, there were several books fitting the criteria; however, the lack of available texts in Korea suggests that the number of children's picture books is disproportionate to the current growing demographic (Leininger, Dyches, Prater \& Heath 2010).

\section{Criteria for Text Inclusion}

After a preliminary review of the available texts relating to multicultural families and friends, four specific 
criteria were developed in order to narrow the focus of the inquiry. The first criterion stipulated that the text must be a picture book (excluding coloring books and young-adult fiction). The primary interest of the study is how pictures and text concomitantly portray constructs and messages regarding multiculturalism, both visually and contextually, specifically for the younger reader.

The second criterion focused only on texts that purposely addressed diversity, explicitly mentioning the term either in the title or in the listed book description. The author's intent had to be specifically stated in the text, as the study did not want to infer authors' intent onto characters. This specificity allowed for a more in-depth analysis. The third criterion eliminated informational texts, such as educational and framed stories, because our focus was on storybooks that include elements of character, story development, and plot, which allow students to view multicultural families from a literary perspective. For our fourth criterion, books portraying animals or inanimate objects were excluded, so that the sample could specifically focus on realistic texts depicting lifelike characters. The study was particularly interested in how multicultural children were characterized, so that we would have a more accurate representation of how these books represent real-world experiences.

\section{Content Analysis}

For this study, a content analysis approach was used, which is a qualitative or quantitative literacy research method that allows researchers to extract, analyze, and interpret the covert or overt messages presented in a text by identifying the intersecting relationships between recurring words or themes (Hoffman, Wilson, Martinez, \& Sailors, 2011). During a content analysis, recurring patterns provide the basis for interpretation and can "reveal the more subtle messages imbedded in a text read by a child in a classroom or by a classroom teachers" (Hoffman et al., 2011, p. 28). The purpose of this study was to examine children's picture books about multicultural families or children to uncover recurring themes and messages.

\section{Data Analysis}

Consistent with content analysis, the study reviewed texts that involved the "inspection of patterns in the written text, often drawing on combinations of inductive, deductive, and abductive analytical techniques" (Hoffman et al., 2011, p. 29). The process started deductively, then inductively, then abductively (Hoffman et al., 2011). Content analysis here served as "the method of making inferences from texts and making sense of those interpretations in a context surrounding the text” (Hoffman et al., 2011, p. 30). Total samples of 40 books were read to determine if they met the criteria for the study, of the forty book only nineteen books were used for the research (see appendix A).

The first step was to perform a "picture walk," in which only a book's illustrations were examined. This helped researchers to understand if individuals from diverse backgrounds were easily identifiable in the text, and also to determine if the overall message of the book could be gleaned from its illustrations alone. Then, the book was read again, reviewing both pictures and text concurrently, and making descriptive notes regarding: (a) general impressions about the text, (b) characteristics of children from a diverse or multicultural background, and (c) how children were treated by others. The goal was to gather further evidence from the books to support emerging findings, and to strengthen our understanding of the messages presented in the texts (Charmaz, 2006). 


\section{Findings}

An analysis of the books identified three significant themes, and one finding that was not included in the study (Erickson, 1986). The empirical findings regard how children's picture books about multiculturalism were available in classrooms (Erickson, 1986).

Affirmation 1: There is a lack of children's picture books reflecting diversity and enriching and enlightening all children.

It is important for students to realize that being from a diverse culture should not be a stereotype, but rather an opportunity to explore new cultures. Specifically, the study found only one Korean book and two translated American books addressing diversity. The Korean published book, 예슬이 엄마 이름은 구티엔, is the story of two little girls, one Korean and one Vietnamese. The girls are classmates who live in the same building. The girls share different parts of their culture, focusing on food, clothing, and physical appearances. The multicultural focus of this story is very obvious: the girls are from different backgrounds, and discover their differences from each other. This book represents the rapidly-changing society of Korea, and shows tolerance of others and children's acceptance of others.

The second book was The Sandwich Swap, a translated American book. The story is about Lily and Salma, who are best friends who go to the same school. They are inseparable, and do everything together. Some of the activities they do together include art projects, playing on the playground, swinging on the swings, jump-roping and eating lunch together every day. One day, Lily and Salma are enjoying lunch together at school when Salma pulls out a hummus and pita sandwich, while Lily has a peanut butter sandwich. The girls look at each other's sandwiches and each says the other's looks "yucky.” This creates a lot of despair, and the girls stop being friends due to their differences. The Sandwich Swap focuses on tolerance of others who are different from you, and how conflicts can be resolved. The end of the story gives a positive message about coming together and not being afraid to try things that are new to you, and teaches children that your best friends can be completely different from you and may like different things and come from a different place, but that does not make them any less of an honorable person or a friend.

The third book, The Color of Us, is also a translated American book. Lena, born in Guatemala, is "seven. I am the color of cinnamon. Mom says she could eat me up ." She learns during a painting lesson that to get the color brown, she will have to "mix red, yellow, black, and white paints ." Lena goes for a walk to observe the many shades of brown: she sees Sonia, who is the color of creamy peanut butter; Isabella, who is chocolate brown; Lucy, who is both peachy and tan; Jo-Jin, who is the color of honey; Kyle, who is "like leaves in fall"; and Mr. Pellegrino, who is the color of pizza crust, golden brown. Lena realizes that every shade is beautiful, and then she mixes her paints accordingly to paint portraits of her friends. The Color of Us focuses on the differences of children, pointing out that friends may be different on the outside but similar on the inside. The book celebrates the beauty of cultural diversity that exists in the uniqueness and variety of skin colors.

While these books are a great reminder of the rapid growth of immigration to Korea, they also remind us of the lack of books that are necessary to facilitate the knowledge and understanding required to provide a smooth transition for children from one culture to a second culture. 
A review of American school libraries shows a more diverse collection of books. The Color of Us and The Sandwich Swap were both included in the American library. For the purpose of this paper, several more books will be reviewed, while the full list of books is located in Appendix A.

The first American book is Too Many Tamales. Maria is helping her parents make tamales for Christmas dinner when she sees her mom put her beautiful diamond ring down while she tends to the cooking. Maria can't help but notice how gorgeous the ring is, and it catches her eye. She decides to try the ring on, just for a moment, but before she notices, the ring is gone. In a panic, Maria looks everywhere, and thinks that it must have fallen into the tamale dough. Instead of going straight to her mother, who she assumes will be upset, she enlists the help of her cousins. They decide that they will eat every single tamale until they find the ring. The cousins eat all the tamales and do not find the ring, although Maria's cousin Danny thinks he might have swallowed it. Maria knows that she must fess up to her mother about what happened, and when she goes to do so, she realizes that the ring is on her mother's hand! The family gets together to make a new batch of tamales for dinner.

The most notable multicultural focus in Too Many Tamales is family and tradition. Holidays are a huge time of tradition in families from all different kinds of backgrounds, especially when it comes to food and activities. It is important for students to be aware that their classmates and friends might not celebrate the same holidays that their families celebrate.

The second American book is Suki Kimono. Suki has a blue Kimono, which was a gift from her obachan (the Japanese word for aunt), and it is her favorite possession. She wants to wear it to her first day of school, even though her sisters tell her that she should wear something newer and more "cool." Suki does not care what they say, and she wears it anyways. When Suki gets to school, she is teased and laughed at by the other students. The students talk about what they did over the summer break, and when it is Suki's turn, she tells the class an elaborate story about how she went to a festival with her obachan and they participated in a circle dance. While telling the story, she gets so passionate about it that she actually starts humming the music and re-enacting the dance that they did at the festival. This time, the reaction from the other students is much different. They applaud her and are entertained.

This book teaches students that to have pride in one's culture is important, no matter what others might think about it. An underlying theme of this book is to "walk to the beat of your own drum," as Suki did quite literally in this story. She shows that it is okay to be yourself, even when people might not understand you. The story provides a glimpse of Japanese culture, and students learn about the traditional "kimono" worn by Japanese women, as well as the word "obachan."

The final American book is I Have a Dream. On August 28, 1963, on the steps of the Lincoln Memorial during the March on Washington, Martin Luther King gave one of the most powerful and memorable speeches in American history. His "I Have a Dream" speech brought his inspiring message of freedom, equality, and peace to the youngest Americans - those who would one day carry his dream forward for everyone. This book's theme of equality and freedom for all are not only relevant today, 50 years later, but also provide young readers with an important introduction to America's past.

Affirmation 2: Children's book depict various cultures and the nationalism that individuals have their own culture 
It was difficult to find many books relating to this question in Korean children's picture books. One book that did so was 마음은 다 같아요. The book shows Ji Eun and his family visiting her grandmother's tofu factory, where he sees workers from various countries, primarily from Cambodia. The grandmother shows the acceptance of Cambodian workers by saying hello in their native language, instead of forcing them to assimilate into Korean society. The book stereotypes workers from lower socioeconomic nations by showing their work in factories, but displays a genuine commitment to the acceptance of others.

The second book is titled 인도에서 온 손님. The book focuses on Woong, who is excited to meet one of his father's foreign guests from work. The boy asks his mother what country the man is visiting from, but instead of letting his mother answer, he lists various countries. Finally, his mother replies, "India," and she continues to tell him about the Ganges River and other places in India. When the father and his guest returned home, the little boy was scared and hid behind his mother's skirts. The guest's face was scary: his eyes were big and his face was black. The father told his son to say hello, but the boy hung on his mother's skirt. His mother grabbed his hand and brought it forward to greet the guest in a proper manner. Throughout dinner, the boy stared at the guest until his mother made him stop. After dinner, the boy asked his mother about the language that his father and the guest were speaking, and she told him it was English. The little boy learned through his parents that the man worked on hybrid cars, and through his love of cars, the boy opened up to the guest, who told him stories and dreams.

The primary multicultural theme of this book is that the boy conquered his prejudice towards others by learning more about others, finding coming ground.

The American book I Hate English is the story of Mei Mei, whose family moved from Hong Kong to New York. Mei Mei suffers from culture shock throughout the move, and the book focuses on Mei Mei’s fear of losing her cultural identity, and her consequent refusal to speak English. Although Mei Mei is welcomed in New York, she suffers from the sense that the subject positions available to her are diminished. Gradually, Mei Mei learns to engage with the language around her, continuing to explore and value Chinese while she acquires English.

The next book is called The Name Jar. Unhei leaves her home in Korea to move to the United States, and before she leaves, her grandmother gives her a special stamp with her name in Korean on it. When she first gets to America, she feels left out and different. The other students can't pronounce her name, and they make fun of her. She decides that she wants to change her name to something American, but she has a hard time coming up with an American name. The students in her class make a "name jar" in which they put their suggestions for what Unhei's American name should be. She meets a boy at a Korean supermarket, and he hears her Korean name and loves it. He tells her that he does not want her to change her name, and he takes the name jar from her. Unhei soon finds out that he, too, has a special stamp with his name on it.

This book talks about the transition from one culture to another, and how children might want to change themselves to "fit in" better. In this story, Unhei finds someone who has a similar background to hers, and she feels more welcome and able to keep her old culture while also adapting a new one. The main theme of this book is to not let go of your old culture completely, nor forget where you came from, just because you are submerged in a new culture.

Affirmation 3: Children's books relating to tolerance and the appreciation of diversity and the ability to accept others. 
The Korean book 용감한 엄마, 콜리 is the story of a little girl whose mom is from the Philippines, and the struggles that the family must face, including their communication background, the differences in cooking, and the love of a daughter for her mother. The book tries to help children look at cultures from different countries without prejudice.

The next Korean book, 색깔의 차이야!, focuses on the acceptance of the color black, stating that black is good. The children point out many items that are black, stating that the color is good. The book also lets children know that many people who are black are good. The book failed to accomplish its goal, however, because of the lack of this concept throughout.

The first American book is I Am America. The author Charles Smith, Jr. has created a poignant, stunning photographic picture book that celebrates the many faces that make up America. "I am America/ I am proud/ I am diverse/ soft-spoken/ and loud." The powerful poem in this one-of-a-kind book is enhanced by the accompanying photographs, which represent children of diverse ethnic and racial backgrounds. The playful images and touching poetry work together to tell the story of America. Children and parents alike will be moved by each unforgettable face and each strikingly beautiful line of verse. It reinforces that although we may look different, we are all American and all the same.

In Amazing Grace, Grace adores play-acting and dressing up as her favorite fictional characters. When her teacher announces that her class is going to put on the play "Peter Pan," Grace immediately volunteers herself as Peter. Some of her classmates protest, telling her that she can’t be Peter Pan as he’s a boy, and he’s not black. This upsets Grace. But when her Ma and Nana hear about what the children have said, they explain to Grace that she can be anything that she wants to be if she has determination. Nana takes Grace to the ballet, where the lead dancer is a beautiful black girl. Grace realizes that her family is right: she can be anything that she wants to be. At the school auditions, all the children vote for her, and she is given the role of Peter Pan. The play is a great success, and Grace gives a magical performance. The book shows that with hard work, everyone can achieve their dreams.

The last book is Whoever You Are. This beautiful picture books affirms that children all over the world have differences (ie: color, race, education, homes, etc.), but that every child shares common ground. Every child loves, laughs, smiles, and cries. The author does explain that every child is different, but the author also mentions the similarities all children have. It shows acceptance and tolerance for all.

Affirmation 4 Illustrations have the ability to persuade young children

The portrayals of multicultural children in the books reviewed here were consistently positive in their portrayal, realistic situation, and exclusion of stereotypes. The illustrations supported children and showed that diverse children are like everyone else. The illustrations contribute to the acquisition of intercultural competence: experiencing the commonality of human experience, exploring cultural identities, and the ability to change perspective. One Korean book did show strong stereotyping of individuals from different countries (Book 1), as the book's illustrations showed people around the world dressed in their traditional outfits. For example, the book showed Native Americans in front of a teepee wearing a headdress and outfit, and Alaska Natives living in an igloo. The stereotyping of these and other nationalities was not done in an attempt to show racial bias, but to show the traditional outfits of people around the world. 


\section{Discussion}

Picture books that authentically reflect cultural diversity can move even young children towards a flexibility of perspective. The often-essentialized illustrations in picture books are influential for cultural transmission, and we find in them a major instrument for cultural transmission and a source of concern for the effect that stereotyped images may have (Clarke \& Clarke, 1990). In picture books, illustrations are a vital component of storytelling, and these books frequently provide gripping access to empathetic characters, as well as individualized cultural details.

Ultimately, pictures may transform into dynamic mental images that remain in the reader's repertoire of experiences, anchoring ideas, concepts, and feelings. Contemporary and innovative creators of literature on serious themes are increasingly turning to visual narratives, and picture books on important topics can make a breadth and depth of understanding achievable. Despite increasing diversity, picture books that feature non-stereotypically diverse populations remain a rarity.

Children's literature is still not authentically portraying a multiethnic Korea. The results of this study show that children who interact with current picture books predominantly see Korean faces. Finding books depicting non-Korean characters, particularly books depicting culturally specific elements, is rare, although there are books depicting culturally neutral and generic characters. This lack of titles that feature ethnically-diverse characters tell non-Korean children that they do not matter, and can inhibit them from developing a positive self-identity, although some might say that the dominance of Korean characters reflects the diversity of the Korean population (97\% of the Republic of Korea population is Korean) (Statistics Korea 2016).

Children's book publishers should promote ethnically diverse books containing representations of diverse populations. According to Harris (1991a, 1991b), multicultural litera-ture, specifically culturally-conscious literature, although desired by educators, enough income for publishers and therefore is less likely to be published. It is necessary, however, to educate staff on the nuances of racism and privilege and to move toward a state of deeper understanding.

This study has implications for research and pedagogy in the fields of education and children's literature, as issues of diversity should be and continue to be at the forefront of the discussion. The findings of this study can be used to help teachers become more aware of which diverse populations are and are not being represented in contemporary picture books, and can allow them to critically examine the range of diversity represented in the books, authors, and illustrators that they choose to include in their classrooms and curricula. A truly multicultural curriculum reflects the range of diversity found in society, including ethnicity, gender, and disability. Exploring and exposing children to a range of diverse populations will increase awareness and understanding of our pluralistic society (Gollnick \& Chinn, 2013; Landt, 2013). As Korea becomes increasingly more multicultural, a child's education should become so as well. "Culturally responsive classrooms specifically acknowledge the presence of culturally diverse students and the need for these students to find relevant connections among themselves and with the subject matter and the tasks teachers ask them to perform” (Montgomery, 2001, p. 4 ). One way to acknowledge the presence of diverse students is to include representations of their diversity in the literature used in the classroom. 
In addition, having a variety of diverse populations depicted in the literature we share with children can help children become literate and engage with their own learning (Hughes-Hassel et al., 2009). Students are more likely to read and value the importance of reading when they see characters that are like them, and with whom they are able to connect (Hefflin \& Barksdale-Ladd, 2001). Children are interested in reading about themselves, in terms of characters, settings, and experiences. When students identify with the characters and situations they find in text and illustrations, their level of reading enjoyment increases (De León, 2002). However, although our classrooms are culturally and ethnically diverse, the books predominantly found in classrooms portray only one race. What does that tell our students? Seeing diverse populations in children's literature needs to become the norm, not the exception. The lack of diversity in children's literature indicates that educators will need to make special efforts to seek out and use quality books that include diverse characters and situations, and that publishers should increase their efforts to make available picture $\neg$ books that include a variety of topics and cultures, so that all children feel valued. As the late Walter Dean Myers (1986) argued, all children have the right to read stories depicting their lives and experiences, and all children have the right to write stories depicting their lives and experiences.

\section{References}

Berg-Cross, L., \& Berg-Cross, G. (1978). Listening to stories may change children's social attitudes. The Reading Teacher, 31, 659-663.

Black, C., Seeman, J., \& Trobaugh, L. (1999). Using children's literature to increase prosocial behaviors in the early years. Saint Xavier University Action Research Project.

Boutte, G. S. (2002). The critical literacy process: Guidelines for examining books. Childhood Education, 78(3), 147-152.

Burns, M. P., \& Sommerville, J. A. (2014). I pick you the impact of Fairness and race on infants' selection of social partners. Frontier in Psychology, published online 2014 Feb 12.

Cai, M. (2002). Multicultural literature for children and young adults. Santa Barbara, CA: Greenwood Press.

Canales, J., Lucido, F., \& Salas, R. G. (2002). Multicultural literature: Broadening young children's experiences. Education Resource Information Center (ERIC).

Charmaz, K. (2006). Constructing grounded theory: A practical guide through qualitative analysis. Thousand Oaks, CA: Sage.

Chaudhri, A., \& Teale, W. H. (2013). Stories of multiracial experiences in literature for children, ages 9-14. Children's Literature in Education, 44(4), 359-376.

Clarke, J. \& Clarke, M. (1990). Stereotyping in TESOL materials. In B. Harrison (Ed.), Culture and the language classroom (pp. 31-44). Oxford: The British Council.

Colby, S. A., \& Lyon, A. F. (2004). Heightening awareness about the importance of using multicultural literature. Multicultural Education, 24-28.

Cox, S., \& Galda, L. (1990). Multicultural literacy: Mirrors and windows on a global community. The Reading Teacher, 43(8), 582-589.

De León, L. (2002). Multicultural literature: Reading to develop self-worth. Multicultural Education, 10(2), 49-51.

Diamond, B. J., \& Moore, M. A. (1995). Multicultural literacy: Mirroring the reality of the classroom. New York, NY: Longman.

Erickson, F. (1986). Qualitative methods in research on teaching. In M. C. Wittorck (Ed.), Handbook of research on teaching (3rd ed., pp. 119-161). New York, NY: Macmillan. Friedlander, D. (2009). Sam comes to school.

Feelings, T. (1985). Illustration is my form, the Black experience, my story and my content. The Advocate, 4(2), 73-82.

Freeney, S., \& Moravcik, E. (2005). Children's literature-A window to understanding self and others. Young Children, 60(5), 20.

Gollnick, D. M., \& Chinn, P. C. (2013). Multicultural education in a pluralistic society (9th ed.). Boston, MA: Pearson.

Hall, K. W. (2008). Reflecting on our read-aloud practices: The importance of including culturally authentic literature. Young Children, 63(1), 80-86.

Hamilton, M., Anderson, D., Broaddus, M., \& Young, K. (2006). Gender stereotyping and under-representation of female characters in 200 popular children’s picture books: A twenty-first century update. Sex Roles, 55(11-12), 757-765. 
Harris, V. J. (1991a). “Have you heard about an African Cinderella story?”: The hunt for multiethnic literature. Publishing Research Quarterly, 7(3), 23-36.

Harris, V. J. (1991b). Multicultural curriculum: African American children’s literature. Young Children, 46(2), 37-44.

Hefflin, B. R., \& Barksdale-Ladd, M. A. (2001). African American children's literature that helps students find themselves: Selection guidelines for grades K-3. The Reading Teacher, 54(8), 810-819.

Hoffman, J. V., Wilson, M. B., Martinez, R. A., \& Sailors, M. (2011). Content analysis: The past, present, and future. In N. K. Duke and M. H. Mallette (Eds.), Literacy research methods (pp. 28-49). New York, NY: Guilford.

Hughes-Hassell, S., Barkley, H. A., \& Koehler, E. (2009). Promoting equity in children’s literacy instruction: Using a critical race theory framework to examine transitional books. School Library Media Research, 12, 1-20.

James, J., Kormanski, J., \& Kormanski, L. (1999). Positive intergenerational picture books for young children. Young Children, 54(3), 32-38.

Katz, P. A. (2003). Racists or tolerant multiculturalists? How do they begin? American Psychologist, 58, 897-909.

Korean Statistical Information Service. (2015).

Korean Statistical Information Service. (2016).

Koss, M. D., (2015) .Diversity in contemporary picturebooks: A content analysis. Journal of Children Literature, 4l, $32-42$.

Kuperus, C. G. (1992). Using interaction with children's literature to positively affect the global and multicultural/multiethnic knowledge and attitudes of third-grade students. Michigan State University, MI: An action research project.

Lamme, L., \& McKinley, L. (1992). Creating a caring classroom with children’s literature. Young Children, 48(1), 65-71.

Landt, S. M. (2013). Children's literature with diverse perspectives: Reflecting all students. The Dragon Lode, 32(1), 21-31.

Langer, J. A. (1995). Literature and learning to think. Journal of Curriculum and Supervision, 10(3), 207-226.

Leininger, M., Dyches, T. T., Prater, M. A., \& Heath, M. A. (2010). Newbery award winning books 1975-2009: How do they portray disabilities? Education and Training in Autism and Developmental Disabilities, 45, 583-596.

Levin, F. (2007). Encouraging ethical respect through multicultural literature. The Reading Teacher, 61(1), 101-104.

Mann-Boykins, J. K. (2016). What the children are reading: A content analysis of minority male characters in preschool children's libraries.

McGlenn, J. (2001). Seeing themselves in what they read. Book Links (pp. 50-54).

Mendoza, J., \& Reese, D. (2001). Examining multicultural picture books for the early childhood classroom: Possibilities and pitfalls. Early Childhood Research \& Practice, 1-32.

Montgomery, W. (2001). Creating culturally responsive, inclusive classrooms. Teaching Exceptional Children, 33(4), 4-9.

Myers, C. (2014, March 15). The apartheid of children's literature. The New York Times Sunday Review, Opinion, pp SR1.

Myers, W. D. (1986, November 9). I actually thought we would revolutionize the industry. The New York Times, Section 7, pp 50.

Norton, D. (1990). Through the eyes of a child. New York, NY: Macmillan.

Rasinski, T. V., \& Padak, N. D. (1990). Multicultural learning through children’s literature. Language Arts, 67(6), 576-580.

Roethler, J. (1998). Reading in color: Children's book illustrations and identity formation for Black children in the United States. African American Review, 32(1), 95-105.

Rosenblatt, L. (1938). Toward a cultural approach to literature. College English, 7 (8), 459-466.

Taylor, D. (1976). Lee and low books, book talk with Debbie Taylor: Author of sweet talk in Harlem. New York: NY Lee \& Low Books.

Taylor, F. (2003). Content analysis and gender stereotypes in children’s books. Teaching Sociology, 31(3), 300-311.

Temple, C., Martinez, M., \& Yokota, J. (2010). Children's books in children's hands: An introduction to their literature (4th ed.). Needham Heights, MA: Allyn and Bacon.

Willett, G. P. (1995). Strong, resilient, capable, and confident. Horn Book Magazine, 71(2), 175-180.

Xiao, N. G., Wu, R., Quinn, P. C., Liu, S. Y., Tummeltshammer, K. S., Kirkham, N. Z., Ge, L. Z., Pascalis, O., \& Lee, K. (2017). Infants Rely More on Gaze Cues From Own-Race Than Other-Race Adults for Learning Under Uncertainty, Child Development. Journal Society of Research in Child Development, doi:10.1111/cdev.12798. 
Appendix

\begin{tabular}{|c|c|c|c|}
\hline Title & Author & Illustrator & Publisher \\
\hline I Hate English & Ellen Levine & Steve Bjorkman & Scholastic Inc. \\
\hline I am America & Charles R. Smith & & Scholastic Inc. \\
\hline I Have a Dream & Martin Luther King & Kadir Nelson & Schwartz \&Wade Books \\
\hline The Sandwich Swap & Queen Rania Al Abdullah/ Kelly Dipucchio & Tricia Tusa & Disney Hyperion Books \\
\hline To Many Tamales & Gary Soto & Ed Martinez & Puffin Books \\
\hline Suki Kimono & Chieri Uegaki & Stephane Jorisch & Kids can Press \\
\hline The Name Jar & Yang sook Choi & & $\begin{array}{l}\text { Knopf Books for Young } \\
\text { Readers }\end{array}$ \\
\hline Amazing Grace & Mary Hoffman & Caroline Binch & Dial Books \\
\hline The Color of Us & Karen Katz & & Square Fish \\
\hline Whoever you Are & Mem Fox & Leslie Staub & Reading Rainbow Books \\
\hline 제목 & 글 & 그림 & 펴낸곳 \\
\hline 예슬이 엄마 이름은 구티엔 & 임희옥 & 김충식 & 아이코리아 \\
\hline 샌드위치 바꿔 먹기 & 라니아 알 압둘라 왕비, 켈리 디푸치오 & 트리샤 투사 & (주)푸른책들 \\
\hline 살색은 다 달라요 & 캐런 카츠 & 캐런 카츠 & (주)푸른책들 \\
\hline 마음은 다 같아요 & 임희옥 & 에스더 & 아이코리아 \\
\hline 인도에서 온 손님 & 임희옥 & 희우 & 아이코리아 \\
\hline 용감한 엄마, 콜리 & 임희옥 & 정다윤 & 아이코리아 \\
\hline 색깔의 차이야! & 임희옥 & 송수미 & 아이코리아 \\
\hline 용과 선녀의 나라 & 도 옥 루이엔 & 박경화 & 정인출판사 \\
\hline 지혜로운 아펜디의 대답 & 이나직 & 윤주혜 & 정인출판사 \\
\hline
\end{tabular}

